\title{
The inclusion of social aspects in power planning
}

\author{
Fernando Ribeiro, Paula Ferreira , Madalena Araújo \\ Department of Production and Systems, University of Minho, Portugal
}

\section{a b s tract}

This paper overviews previous research addressing the inclusion of the, social dimension of sustainable development on power systems planning. Consequences of the recent energy policies and strategies are already being felt in, developed countries' power systems, with the integration of rising quotas in renewable, energy technologies. However, while the tools that aid decision making on power, planning show that economic and environmental issues are easily quantifiable and thus, modeled, social concerns have been addressed in a less extensive and more, subjective way, implying in most cases expert participation on multi-criteria decision aid, techniques. A survey of recent papers providing public perceptions on electricity, generation technologies and projects is presented. These papers were chosen and, reviewed in order to present a representative array of methodologies that are used to, assess social acceptance of technologies. According to some of the reviewed papers, this issue is suggested to be fundamental to increase project success. As a conclusion, stands the fact that further discussion is still needed in order to achieve solid, agreement, among experts, over what are the positive and the negative drivers to, social sustainability; otherwise models will not be able to translate reality and improve it, under this point of view.

\section{Contents}

1. Introduction

1.1. Sustainable development and social sustainability

1.2. The social dimension in the electricity decision-making process

2. Public attitude towards electricity generation technologies and related decisions

2.1. Methodologies to address the social dimension of electricity planning

3. Conclusion and future work

Acknowledgment

Annex I

References

\section{Introduction}

In 1997, the Kyoto Protocol was adopted. One decade later, the European Union proposed the so-called "20-20-20" package, which goals are (i) to cut in greenhouse gases (GHG) emissions to at least $20 \%$ below the 1990 levels, (ii) to reach $20 \%$ of renewables' share in the energy mix and (iii) to cut $20 \%$ in primary energy consumption, until 2020. The electricity sector is of major importance for the energy decision makers, as it accounts to, roughly $20 \%$ of the total energy consumed in the aggregate of the 27 countries of the EU. ${ }^{1}$ Also, it still relies mainly on fossil fuel power plants responsible for

Corresponding author. Departamento de Produc, ão e Sistemas, Campus de Azurém, 4800-058 Guimarães, Portugal.

E-mail address: paulaf@dps.uminho.pt (P. Ferreira).

1 Data retrieved from http://epp.eurostat.ec.europa.eu/portal/page/portal/energy/ introduction. high GHG emissions. Although some of these older power plants are to be dismantled within the next decades, the consumption of energy is also expected to increase around $15 \%$ during this period [1]. Therefore, replacement and instalment of new power plants will take place, hopefully taking into account the social, economic and environmental impacts. In the context of this study, electric-ity power planning will be perceived as the process of (i) setting goals for the electricity sector, (ii) designing strategies and policies and (iii) decommissioning and building infrastructures in order to achieve the proposed goals.

As a result of the uncertainty involved, with the economic conjuncture playing a major role, the planning of the electricity power system on a long-range term (10 or more years) is an increasingly challenging issue. For example, before the 70's, no big effort was placed on planning. This view substantially changed after the first oil crisis, at the level of searching for efficient supply options, based mainly on cost optimization objectives [2]. Later, in the 80's, as the 
public became aware of environment devastation, decision-makers started to include environmental issues on the models [3]. The generalization of multi-criteria decision analysis (MCDA) methods gave planners the possibility to address other issues such as land use, human health and reliability of the system [4] and allowed for the explicit integration of the social dimension of the decision making process.

Although the literature related to energy often mentions "sustainability" or "sustainable development", few works actually refer to the social aspects of electricity planning. Therefore, this paper aims to present a comprehensive and multidisciplinary review of the recent literature on this theme, focusing on the concept of social sustainability and public perceptions of electricity generation tech-nologies, both within the scope of the social sciences, plus planning and technical analysis, within the borders of engineering.

The remainder of the article is as follows: in chapter 2 the theoretical aspects of social sustainability are reviewed, presenting an overview of how these have been addressed in the literature; in chapter 3 studies aiming at the inclusion of the social impacts of electricity generation are analyzed; chapter 4 presents some of the methodologies most frequently used to assess public acceptance of electricity generation technologies; based on the review of the literature, conclusions are drawn in chapter 5 and guidelines for future research are discussed and proposed.

\subsection{Sustainable development and social sustainability}

Every citizen of the developed world has been increasingly faced with the expression "sustainable development", whether it hap-pens in the context of climate change, or when one gets conscious that some resources in which we base our society are finite. The most influential definition for sustainable development was pre-sented in the Brundtland Report, where a pattern of resource use is presented that "meets the needs of the present without compro-mising the ability of future generations"[6].

It is widely accepted that Economy, Environment and Society are the three pillars for sustainable development. However, these pillars are often interconnected in real world situations. It should be reminded that Copenhagen's goals address emissions of GHG, which, although related with social impacts (for example, health), is mainly an environmental aspect. No similar global conference exists proposing such a large scale of goals for social sustainability.

Some definitions of social sustainability are now presented, as well as some related questions posed in the literature, which high-light the special characteristics of the concept.

Black [7] states that social sustainability is the continuation of society in the future, implying the continuation of its social values, social identities, social relationships and social institutions. This concern for the future in the long run has also been expressed on Biart [8], definition: "[Sustainability] aims to determine the min-imal social requirements for long-term development (sometimes called critical social capital) and to identify the challenges to the very functioning of society in the long run".

Social sustainability is also underlined by Polese and Stren [9], as a "development (and/or growth) that is compatible with harmo-nious evolution of civil society, fostering an environment conducive to the compatible cohabitation of culturally and socially diverse groups while at the same time encouraging social integration, with improvements in the quality of life for all segments of the popula-tion". Sachs [10] states that "sustainability must rest on the basic values of equity and democracy, the latter meant as the effective appropriation of all human rights - political, civil, economic, social and cultural - by all people".

In the perspective of Griessler and Littig [11] social sustainabil-ity is achieved "if work within a society and the related institutional arrangements (i) satisfy an extended set of human needs and (ii) are shaped in a way that nature and its reproductive capabili-ties are preserved over a long period of time and the normative claims of social justice, human dignity and participation are ful-filled". However, the authors also recognize that suggesting "social sustainability indicators that are drawn from sociological theory is one story. To incorporate them into policy-making and to have an impact is another one."

More recently, Colantonio [12] argues that during the 90's there was an emergence of new social concerns. Based on this assumption the author divides the key themes used on approaches to assess social sustainability in two categories:

- Traditional. (i) Basic needs, including housing and environmental health, (ii) education and skills, (iii) employment, (iv) equity, (v) human rights and gender, (vi) poverty and (vii) social justice.

- Emerging. (i) Demographic change (aging, migration and mobil-ity), (ii) social mixing and cohesion, (iii) identity, sense of place and culture, (iv) empowerment, participation and access, (v) health and safety, (vi) social capital, (vii) well being, happiness and quality of life.

The author argues that social sustainability is gaining recogni-tion as a fundamental dimension of sustainable development. His work also demonstrates that monetization and accounting tech-niques, which exclude participation, still dominate sustainability tools. He also states that, besides the promotion of social capital, few tools for implementing that concept exist.

Vallance et al. [13] reviewed the literature which refers "social sustainability" in somewhat "chaotic, contradictory and confusing" ways. Therefore, the authors took all the approaches to the "social sustainability" concept they could find in the literature, and group them according to the three following strands: (i) development, including literature focusing on the need to meet more or less tan-gible basic requirements and needs (ii) maintenance, referring to papers mainly associated to the peoples preferences on the preser-vation of sociocultural characteristics and (iii) bridging, based on literature addressing ways of involving people on the environmen-tal goals and compromises.

Besides the array of definitions, the literature also addresses some inconsistencies, which arise from these ones. For example Murray et al. [14], raised the questions: "how long something must persist for it to be called sustainable?" "and who's counting?". McKenzie [15] points also concerns with cultural issues as a basis for achieving social sustainability; and presents a feature of a social sustainable society: "a system of cultural relations in which the pos-itive aspects of disparate cultures are valued and protected, and in which cultural integration is supported and promoted when it is desired by individuals and groups". The following question might be asked: is it possible to achieve overall agreement on which are the positive aspects of disparate cultures, in a multicultural society?

As stated in [16] most of the sustainable development discourse has always been focused on environmental sustainability. The same study criticized the Brundtland Report as being too narrow on social aspects, making them coincide with poverty. According to Benaim et al. [17] "the social dimension seems overwhelming. Unlike the environmental and economic systems where flows and cycles are easily observable, the dynamics within the social system are highly intangible and not easily modeled." Plus, as underlined by K: Mis-simer et al. [18] the researcher is part of the social system and as so he cannot observe as an outsider.

These arguments clearly bring the problem of knowledge on social sustainability at a distinct level of the knowledge on ecosys-tems or climatology, where the scientific community can achieve a certain level of agreement, constructing somewhat robust models for forecasting impacts. 
Table 1

Survey of papers addressing social concerns in power systems decision-making.

\begin{tabular}{|c|c|c|c|c|}
\hline Reference & $\begin{array}{l}\text { Methodology which led } \\
\text { impacts to be considered }\end{array}$ & $\begin{array}{l}\text { Number of social } \\
\text { impacts considered }\end{array}$ & Study objectives & $\begin{array}{l}\text { Subsequent models and methods } \\
\text { (application of the impacts as } \\
\text { criteria / indicators) }\end{array}$ \\
\hline Kowalski, Stagl et al. 2009 [19] & $\begin{array}{l}\text { Interviews with Energy } \\
\text { experts, community councilors, } \\
\text { NGO's. Scenario building }\end{array}$ & 5 & Comparison of RES technologies & MCDA (PROMETHEE) \\
\hline Kahraman and Kaya [20] & Literature review & 4 & Comparison of RES technologies & MCDA (Fuzzy AHP) \\
\hline Karakosta et al. [21] & Collection of official indicators & 2 & $\begin{array}{l}\text { Evaluation of energy policy } \\
\text { guidelines }\end{array}$ & SWOT Analysis \\
\hline Roth et al. [22] & Collection of official indicators & 6 & $\begin{array}{l}\text { Comparison of energy } \\
\text { technologies }\end{array}$ & MCDA \\
\hline Gamboa and Munda [23] & $\begin{array}{l}\text { Interviews, including } \\
\text { environmentalists, } \\
\text { governmental and industrial } \\
\text { stakeholders }\end{array}$ & 6 & Wind farm location problem & Social Multi-Criteria Evaluation \\
\hline Doukas et al. [24] & $\begin{array}{l}\text { Group work of } 25 \text { actors from } \\
\text { both public and private energy } \\
\text { companies }\end{array}$ & 2 & $\begin{array}{l}\text { Comparison of innovative energy } \\
\text { technologies }\end{array}$ & $\begin{array}{l}\text { MCDA [Linguistic ordered } \\
\text { weighted averaging (LOWA) and } \\
\text { Linguistic weighted operator } \\
\text { (LWO)] }\end{array}$ \\
\hline GallegoCarrera and Mack [25] & $\begin{array}{l}\text { Literature review and Delphi } \\
\text { Group process with energy } \\
\text { experts }\end{array}$ & 20 & $\begin{array}{l}\text { Comparison of electricity } \\
\text { technologies }\end{array}$ & MCDA \\
\hline Ferreira et al. [5] & $\begin{array}{l}\text { Literature review, interviews } \\
\text { with energy experts and Delphi } \\
\text { Group process }\end{array}$ & 4 & $\begin{array}{l}\text { Comparison of electricity } \\
\text { generation technologies }\end{array}$ & MCDA (AHP) \\
\hline Beccali et al. [26] & (Not explicit) & 3 & $\begin{array}{l}\text { Comparison of renewable energy } \\
\text { technologies }\end{array}$ & MCDA (ELECTRE III) \\
\hline Cavallaro and Ciraolo [27] & $\begin{array}{l}\text { Data set elaborated by the } \\
\text { authors (experimental phase) }\end{array}$ & 5 & $\begin{array}{l}\text { Wind farm dimensioning } \\
\text { problem }\end{array}$ & MCDA (NAIADE) \\
\hline Evans et al. [28] & Literature review & 10 & $\begin{array}{l}\text { Comparison of renewable energy } \\
\text { technologies }\end{array}$ & $\begin{array}{l}\text { Assumed equal weight for every } \\
\text { criteria }\end{array}$ \\
\hline Vera and Langlois [29] & Collection of official indicator & 4 & $\begin{array}{l}\text { Construction of a sustainable } \\
\text { development indicator dataset }\end{array}$ & - \\
\hline Assefa and Frostell [30] & Literature review & 3 & $\begin{array}{l}\text { Sustainability assessment of } \\
\text { energy technologies }\end{array}$ & $\begin{array}{l}\text { ORWARE (Swedish technology } \\
\text { assessment tool) }\end{array}$ \\
\hline Begic and Afgan [31] & Literature review & 2 & $\begin{array}{l}\text { Comparison of electricity } \\
\text { generation technologies }\end{array}$ & $\begin{array}{l}\text { MCDA (ASPID - Analysis and } \\
\text { Synthesis of Index at Information } \\
\text { Deficiency) }\end{array}$ \\
\hline Streimikiene and Sarvutyte [32] & Literature review & 4 & $\begin{array}{l}\text { Comparison of electricity } \\
\text { generation technologies }\end{array}$ & $\begin{array}{l}\text { Assumed equal weight for every } \\
\text { criteria }\end{array}$ \\
\hline Alberts [33] & Literature review & 2 & $\begin{array}{l}\text { Evaluation of wind power } \\
\text { impacts }\end{array}$ & Delphi Inquires \\
\hline Krajnc and Domac [34] & (Not explicit) & 3 & $\begin{array}{l}\text { Socio-economic and } \\
\text { environmental impact modeling } \\
\text { of biomass utilization }\end{array}$ & SCORE model \\
\hline del Río and Burguillo [35] & $\begin{array}{l}\text { Data set elaborated by the } \\
\text { authors }\end{array}$ & 13 & $\begin{array}{l}\text { Sustainability assessment of } \\
\text { renewable energy projects in } \\
\text { rural areas }\end{array}$ & $\begin{array}{l}\text { Elaboration and comparison of } \\
\text { case studies (empirical study) }\end{array}$ \\
\hline Werner and Schäfer [36] & Literature review & 3 & $\begin{array}{l}\text { Social Sustainability of a specific } \\
\text { location solar-power project }\end{array}$ & $\begin{array}{l}\text { Interviews and questionnaires in } \\
\text { local community }\end{array}$ \\
\hline
\end{tabular}

Last but not least, actually a major issue, as Murray et al. [14] puts it: if social sustainability is about equity, whose notion of equity should prevail?

Although the concept of sustainability is far from being con-sensual and scientifically exhausted, from this literature review on sustainable development and social sustainability, some basic conclusions may be drawn:

(i) Social sustainability is a multi-dimensioned theme and no satisfactory definition has been made, since none seems to be generally accepted.

(ii) Social sustainability aspects have been changing through time, although, if a hierarchic approach is to be made, "quality of life" should prevail on top.

(iii) Although the matter of time horizon of consideration in sustainability objectives is still not fully established, sustainability definitions always envisage the future generations' wellbeing in the long term. (iv) Environmental issues can affect the whole planet, so they demand global response; the main example is the Kyoto Protocol, where the scientific community gathered and defined goals in terms of GHG emissions. No parallel exists in the social pillar of sustainability.

\subsection{The social dimension in the electricity decision- making process}

Economic concerns were the main ones from the beginning of power systems planning when decisions had to be made, so economy tools have obviously been employed for a long time for example for the minimization of cost function, risk analysis or financial project evaluation. More recently, the consensus that emerged from the Kyoto Protocol resulted in goals set for each Euro-pean country at the level of GHG emissions. Thus, it became urgent for decision makers to impose limits on power systems' emissions and, as a result, it became important to model these emissions. It is clear that, being the environment such a complex system, the 
ecologic pillar of the sustainable development is a wider theme than GHG emissions, but we can state that, to some extent, this pil-lar has also been addressed in a measurable way: GHG emissions function and its institutional restrictions. As stated in the previous chapter the social pillar is traditionally the weakest one; from the literature review, one is led to agree, since less papers address it and no clear institutional restrictions exist.

Table 1 demonstrates a survey of papers published since 2000, aiming to provide the variety of methodologies which supported the selection of social impacts to be included in each study. Table 1, below, indicates also how many impacts are chosen and how they are applied. See Annex I for the complete list of social impacts surveyed.

Nineteen studies were reviewed, with 101 impacts identified in the total. Three of the studies $[21,22,29]$ relied on an approach based on institutional indicators datasets. On the other hand, five included participative methodologies to obtain field information - individ-ual interviews $[5,23]$ or group activities [19,23-25]. The remaining ones either retrieved the required information from the literature; or do not make that information explicit, or the researchers them-selves built the dataset.

The choice for the participative methodology highly depends on features of the project, e.g. aspects such as geographical scope, number of participants, budget and time frame must be consid-ered. For a complete review of these participative methodologies see [37]. Although surveys and household interviews are not so common in this phase, as GallegoCarrera and Mack [25] recall, the direct assessment of citizen's personal options may be preferable for some indicators; however this may be difficult to implement due to the frequently large amount of data that must be collected to obtain the intended results. Also Diakoulaki [38] underline that these participative methods are still usually costly and time con-suming processes. Besides, it is rather likely that a random citizen may overestimate the possible risks of one technology, as he is not well informed (while believing he is) on technical issues such as the impact of the integration of a certain amount of installed power of a certain technology on the reliability of the whole electrical sys-tem. Thus, the population is represented by well-informed groups (NGO, community councilor and energy experts which are aware of the population attitude), in the case of $[19,25]$.

Regarding the number of indicators or criteria chosen on each work, no conclusion can be drawn, since it is fairly independent of the methodology of acquisition of indicators, and depends more on the methodology of their application. For example, AHP relies on pairwise comparisons, so it is particularly suitable for a controlled number of criteria.

From the total 101 impacts identified on the set of papers surveyed, the most referred issues are employment (10 times), change in land cover (8 times), production of toxic chemicals (7 times). Annoyance by noise is mentioned 6 times, income inequalities ( 5 and investment 4 times).

There are some other impacts that, although not referring to sustainable development at least at an immediate level, can influence decision-making in electricity planning. Three distinct categories seem to emerge: Social Acceptance (9 occurrences), Technical Aspects (3 occurrences) and Risk Factors (11 occurrences). Market aspects are also evoked in some works, although these fall on the economic pillar of sustainable development (for example "market maturity" and "diversity of energy suppliers").

Due to the complexity and conflicting objectives of the the-matic involving social concerns, it was found that its application on decisionmaking falls mostly on MCDA: 12 of the studies use it, although recurring to different techniques, with the exception of Analytic Hierarchic Process (AHP) $[5,20]$. The literature on MCDA techniques is abundant, and a detailed description of electricity planning with MCDA may be found for example in [39].
Although MCDA techniques are the majority, other well-known policy aiding techniques are also present on the literature, such as Delphi inquiries [33] and local interviews [38] for project acceptance assessment, SWOT Analysis [21] and case studies [35]. There are also other applications that are not so widespread, such as ORWARE [30] and SCORE model [34].

This section provided a description of the most relevant social impacts addressed in the literature, which should be taken into account in subsequent energy decision making models and methods.

Literature on the assessment of the public opinion and social acceptance or opposition to electricity generating projects is much more profuse. Section 2, far from being exhaustive, aims to address this issue presenting a general overview on public attitude towards electricity generation technologies and on methodologies that may be considered for the assessment of public opinion.

\section{Public attitude towards electricity generation technologies and related decisions}

The possibility to please all the population at the same time in a process like national electricity planning has to be discarded, given the number of citizens affected by an array of impacts and their unequal distribution among the population. The reasons for this unequal distribution are, among others, geographical (for visual and noise amenities) and economic (given the inequality of pur-chasing power). Formulating a unique optimal plan is unlikely to be a realistic objective and controversial decisions will always have to be taken, as stated in Ferreira [40]. Authors like Upham and Shackley [41] argue that, although a difficult and costly pro-cess, the enhancement of local participation in energy planning may lead to more widely acceptable outcome. On the other hand, Alberts [33] states that it can be more productive to consult tech-nical experts than to seek consensus from all stakeholders, as the potential participants may not have sufficient experience or knowl-edge to effectively contribute to the decision making process.

Given its rising importance, it seems that a significant num-ber of controversies reported in the literature addresses wind power projects (see, for example, [42-44]) where noise, visual and bird strike stand as important concerns. Despite what has been described as a general positive attitude towards renew-ables [45], some of these projects face resistance, which may delay the completion of the project [27]. However, other forms of energy can also face opposition, some of them involving renew-able energy projects, which apparently is a contradiction, given their already mentioned high level of general acceptance. A recent example is the hydropower project in the north of Portugal that faced resistance from a civic movement, ${ }^{2}$ opposing themselves to the impacts of the dam, namely submergence of the histor-ical train line, besides visual intrusion and consequences in the agricultural sector. Also, Upreti [46] reported the opposition to a proposal of a combined cycle biomass gasifier in the UK, mainly because of truck movements, pollution and odor. In the case of nonrenewable energy projects, nuclear power has been debated for decades. See the recent example of Sjoberg [47], which describes the fear of the Swedish population towards waste from nuclear power plants. Other examples of technologies facing opposition such as carbon capture and storage, and hydrogen are delivered in Section 2.1 .

The decentralization of the electricity production in power sys-tems tends to grow with the increasing integration of numerous smallerscale power plants. These are spread according to the

2 See http://www.linhadotua.net/ (in Portuguese) for more information. 
distribution of the renewable resources; therefore, getting closer to the consumer, possibly present in his daily life landscape [48]. The term NIMBY (acronym for Not In My BackYard, popularized in the 80 's by the British politician Nicholas Ridley) classifies the attitude of citizens who generally agree with a given project (not necessarily related to energy), but oppose it if it is to be done in their "backyard". This term has been present in the literature associated with wind power since the 80 's and is often regarded as common sense [49].

Wolsink [49] contextualizes NIMBYism as game theory for economists and social dilemma for psychologists: the prisoner's dilemma. The consequence of the prisoners' dilemma is that, although the whole society would be better off if the public good (in that case, wind power) was produced, everyone tries to min-imize private costs (in that case, wind power's negative impacts) and this stimulates the so-called free rider behavior: blocking the development of wind farms in their vicinity, which dominates the social best solution.

Other papers reviewed in [50] tested the NIMBYism hypothe-sis of wind farms and concluded that they do not explain all the resistance that projects faced. In line with this Maruyama et al. [51] argued that community-owned wind programs they reviewed in their work (referring to Japanese examples) seem to move away from the NIMBY attitude. In fact, institutional factors may be more important than NIMBYism, and building institutional capital should improve rates of wind power implementation [49]. Insti-tutional capital implies knowledge resources, relational resources and capacity for mobilization. Gamboa and Munda [23] mention an example in Catalonia, where wind turbines siting was a successful task given the affected population's participation in the decision-making process. The same paper also proved that municipalities' income and job creation favor projects acceptance. Kaldellis [42] research put in evidence the conservative nature of people living in a Greek island near a wind farm development, demonstrating some public opinion divided or mostly against. The author also pointed out other parameters that negatively affected public perception, such as the great amount of concentration of wind turbines. The author believes that additional public information regarding wind energy could improve the levels of acceptance.

Loo [52] even coined the NIMBY's opposite as PIMBY (Please In My BackYard) for the cases in which revenues for the development increase the acceptance of a particular project. Given the variety of opinions in the literature, one may conclude that the validity of NIMBYism is still an open problem.

\subsection{Methodologies to address the social dimension of electricity planning}

The assessment of the public opinion, social acceptance or social opposition to projects falls in the social sciences domain. In this area, the research methodologies are frequently grouped in qualitative and quantitative approaches. "Qualitative, naturalistic approach is used when observing and interpreting reality with the aim of developing a theory that will explain what was experienced" whereas "the quantitative approach is used when one begins with a theory (or hypothesis) and tests for confirmation or disconfirma-tion of that hypothesis" [53]. The authors argue that, depending on the research, both types of methods can be used on their own, but also combined. Recent examples of both types of methodologies applied to particular cases in the scope of electricity planning are described in this section.

Quantitative methodologies appear to be predominant in the published literature of public perception of renewable energy. Ellis et al. [54] reviewed 45 public opinion and attitude surveys made in the UK and Ireland, from which $78 \%$ were quantitative, $18 \%$ qual-itative and $4 \%$ mixed. Devine-Wright [55] collected references for the USA, Canada, Denmark, Sweden, Germany and Netherlands and corroborated that the literature in western developed countries is mostly empirical, and uses quantitative survey.

A set of common methodologies, representative of the whole literature that addresses public perception of electricity generation technologies is presented.

Surveys are a methodology that uses, generally, closed-ended questions (example: "do you know your height?"), although they can include focused, short-answer questions (example: "what is your height?") and multiple choice (example: "from the following list of issues, choose the two which are more important in your opinion"). In all these cases, surveys are considered a quantitative methodology. However, surveys can be open-ended, which implies that space is given to the respondent's own words; in this case, the information obtained is qualitative.

A clear advantage of close-ended surveys' use is the statistical treatment of data collected among large amounts of people, from which it is possible to derive patterns regarding behaviors accord-ing to respondents' age, location and social class, among others. According to the sample size it is possible to determine validity and statistical significance of a survey.

As Devine-Wright [56] states, these studies tend to be successful in describing one-off snapshots of public views, given their statisti-cal significance; but detailed explanations of their causes remain obscure, therefore are useless to build theory. The author also believes that disciplines such as psychology can be helpful in tack-ling this issue providing alternative frameworks for questionnaire surveys, demonstrating the necessary interdisciplinary of future research teams. In spite the aforementioned shortcomings in expla-nations, the general picture taken by the Eurobarometer [45] survey include perceptions at various degrees: importance of the theme ("EU citizens rate energy issues far below unemployment, crime and healthcare systems"), level of knowledge ("Europeans appear to be knowledgeable of the level of energy dependence"), fears ("appear not to fear great societal changes, such as the rationing of energy consumption or not being able to buy a car") and hopes (" $45 \%$ consider that their government should make guaranteeing low energy prices a top priority in their energy prices"). Group distinctions are also perceptible ("males, the highly educated and those in managerial position seem to be more knowledgeable of energy issues").

Surveys size can vary: while the Eurobarometer survey cov-ers 15 topics, Wolsink [49] designed a survey to test the NIMBY's hypothesis, with only five social dilemmas statements, aiming to conclude that the concept might be insufficient to explain opposi-tion to wind power projects. In his case there were 725 respondents, which were residents near three wind farms. The surveys were close-ended ("support" or "reject") and were the following: "Only turbines here if sited elsewhere too", "Turb's create costs, benefits unlikely, uncertain", "Preference for other sites, elsewhere", "We bear costs, elsewhere they don't accept" and "Benefits only for the electricity utilities". The surveys responses were collected during interviews.

Ansolabehere and Konisky [57] also used surveys to perform a comparison of public perception on types of power plants: coal, natural gas, nuclear and wind farm. They assessed perceptions about siting the power plant near the respondents' home, perceived environmental harm and perceived cost.

Surveys are often used in recent literature addressing accep-tance of promising forms of electricity generation; see for example, Wolsink [58] on near shore wind, Warren et al. [59] on tidal energy (this study was complemented with focus groups, see later in this chapter for more information on this methodology), Itaoka et al. [60] on carbon capture and storage, Achterberg et al. [61] on hydro-gen technology, among others.

Within qualitative methodologies, the $Q$ methodology, accord-ing to Brown [62], provides a framework for systematic study 
of subjectivity, personal viewpoints, beliefs and attitude. Its spe-cial feature is the aim of mitigating researcher bias. Ellis et al. [54] used this methodology as they claim that the literature often assumes NIMBY-ism as a valid theory, and they wanted to test it in one year case-study of an offshore wind farm in Northern Ireland. This way, instead of capturing information existing in a whole population, it rather focuses on a selected sample of sub-jects. The authors analyzed texts related to public debate, both for and against wind power in general, along with government policy documents and public debate around the specific offshore wind farm. Put simply, the objective of the whole methodology was to extract 50 statements that summarize viewpoints, which participants were to sort according to their priorities. The result of this research project could deliver information such as "those who oppose the project ask whether decisions are being taken for the right reasons and question the notion that science, policy makers and economists are necessarily working exclusively for the public good", and that "there is a fundamental disagreement over the value of wind energy and its ability to make a major contri-bution to the country's energy needs", among others. Along with the 50 statements, 8 idealized profiles ("factors") were created and it was possible to analyze how much an interviewee fell in which factor.

Wolsink and Breukers [63] used also Q-methodology to iden-tify different perspectives on wind power, among stakeholders of three different countries. The authors identified four different factors, one against wind power implementation and three funda-mentally supportive but for different reasons. Controversial issues were found to be landscape values, participation in the project plan-ning, local decision-making, financial participation and the role of local authorities. The respondents were stakeholders from conven-tional energy sector, private wind project developers, cooperatives and citizen projects, wind power and renewable branches, envi-ronmentalists and landscape preservation organizations, anti-wind power groups, researchers and governmental bodies ranging from local to national bodies.

Among qualitative methodologies, interviews are quite popu-lar, especially with experts. Huijts et al. [64] assess perceptions on carbon sequestration and storage, in two distinct phases, which involved, first, well-informed groups (industrial, governmental, energy companies, NGO) and, later, general public. In the first phase, stakeholders and experts were interviewed, after which they had group discussions; finally, the second phase was the dis-tribution of 103 surveys in two different communities. The main conclusions presented in this work were that all the professional actors showed interest in the technology, while the general public appears to have little knowledge and little desire for more infor-mation, therefore trust (mainly on the NGO) the key for success. The main difference between surveys and interviews stands, thus, in the quality of information: while the surveys had to be represen-tative (103 surveys handled to the population), it would have been time-consuming, costly and probably useless to use interviews, given the little knowledge presented by the general population, which would add no more information than the one presented in the surveys' responses. On the other hand, the interviews with the four wellinformed groups provided information on particularly important issues (costs, technical, legal possibilities, risks), which was precisely the information that the authors were looking for. Therefore, we might emphasize interviews as particularly useful for exploratory phases.

Jobert et al. [50] used five German and French wind park casestudies to evaluate how policy frameworks influence their local acceptance. For each case, eleven and fifteen semi-structured interviews of one to two hours were carried among local actors such as city-council members, journalists, project planners, regional representatives and spokespersons of local associations. Semi-structured interviews are usually based on a guide prepared in advance with questions taking into account the information the researcher is looking for. Contrarily to surveys or structured interviews, the researcher is free to further explore some themes that arise dur-ing the conversation. The authors found it particularly helpful in case-study context, as is the main aim of the paper.

To assess public perceptions on community-based energy projects in the UK, Rogers et al. [65] used both questionnaire sur-veys and semi-structured interviews. The data was collected among rural households: the 46 questionnaires (administrated face to face or by telephone) were used to collect both quantitative and qualitative data, from the closed and open questions, respectively; whereas the nine semi-structured interviews collected qualitative data, among households and businessmen. The interviewees had contrasting views on the theme, and that choice has been made on purpose. The authors argue that the advantage of doing interviews in this case was the possibility to explore other themes related to the main research question.

Gross [43] explored public perceptions regarding procedural justice on a wind farm pilot study. Having been argued that the involvement of community in the process can increase the accep-tance of renewable energy projects, the aim of the study was to propose a community fairness framework, with the intent to aid community consultation and increase social acceptance levels. Twelve semi-structured interviews were made, therefore the key informants selection represented a crucial phase of the methodol-ogy implementation. In order to select individuals able to provide collective and important viewpoints, the authors resourced to snowball or networking effect.

Focus groups is another qualitative research methodology, in which a group of people is asked about perceptions or attitudes towards a certain question, and are free to discuss it. The reviewed papers showed the flexibility of focus groups, since they have been successfully used on their own, or along with other qualitative or quantitative methodologies.

For the assessment of public perception of carbon capture and sequestration, the US Department of Energy used focus groups in five communities of three different regions [66]. The study aimed to derive patterns of commonalities and divergence between the regions. In order to be properly effective as a comparative study between the locations, the protocol was built by three teams of researchers, one of each region. This way, besides seven common topics, intrinsic questions regarding the specific historical, eco-nomic and social profile of each region could be included. Also, a major issue was the choice of the communities to study. This choice was based on the prospect technology installation, so it ranged between very probable and improbable places to do it. Besides inter-regional general attitude comparison, socioeconomic status was taken into account. The authors argue that, although no statis-tical significance could be inferred, the focus groups methodology flexibility was a key factor to the success of the study.

Also, Gough and Shackley [67] used focus groups but combined with surveys to assess carbon capture and sequestration acceptance in the UK. The surveys were used after the focus groups process implementation, and were specifically designed according to these focus groups findings.

More recently, Flynn et al. [68] also resourced focus groups to assess public attitude towards hydrogen, in three regions within the UK which have already installed hydrogen facilities or had plans for developing them. The process consisted in two phases: nine groups in the first and seven in the second, ranging from three to thirteen elements possessing varied socioeconomic backgrounds. The first phase was more geared towards general information on energy and environmental issues. The second phase was focused in hydrogen technologies. The continuation of the project (not treated in that paper) was a series of citizen panels, carried out to engage 
community in a participative and deliberative process about alternative scenarios for hydrogen energy.

\section{Conclusion and future work}

The present work consisted in a review of the literature with the potential to aid the elaboration of a methodology, intended to support the explicit inclusion of the social pillar of sustainable development while planning the expansion of the generation capacity of power systems. The literature review covers fields within engineering and social sciences disciplines. As a major conclusion, interdisciplinary is seen as a tendency in sustainability issues.

The underlying theory of social sustainability was first reviewed. Theoretically, social sustainability appears as a fuzzy concept, although it can, in a very general way, be associated with the quality of life of our society (and its inequalities, health and employment issues) now and in the future.

Chapter 2 was written with the purpose of surveying a list of the most common social impacts associated with electricity generation technologies, as well as the applications in which these impacts are involved. For planning purposes and technology comparison, Multi-Criteria Decision Methodologies are the most frequent application of these indicators and often imply expert participation. The inclusion of the social dimension in power planning still seems to be an open problem, whose roots are the incommensurability of the social dimension of sustainable development. A simple example: renewable energy technologies may have better performances on health and employment issues than the conventional technologies, but if they are more expensive, will they lead to inequalities in the society? From the survey of indicators present on the literature, employment is by far the most cited, which coincides with citizen's worries about life in general, at least in the EU [45].

A set of methodologies for assessment of public and experts opinion on electricity generation technologies are reviewed. Papers presented in this review concluded that citizens' fear about technologies, often backed by lack of knowledge, brings up the need to build trust in institutions [49,64]. Also, the collaboration with both citizens and their representation institutions (being nongovernmental organizations the preferred) can increase success in decision-making.

Upon the literature review, plans are now drawn for future work. A mixed methodology resourcing qualitative and quantitative tools is envisaged. Collaboration with experts in power systems will most likely assume the form of semi-structured interviews. This methodology appears appropriate since its openness will enable the possibility to draw guidelines. Questions like "which generation technologies are available within the next 10 years?" "how much installed power is technically feasible for each of them?", among others should be addressed. It will enable the possibility to retrieve information which appear significant in the eyes of the expert and not present in the guidelines, or explore further some themes.

The list of the social impacts to be considered and further explored is also expected to contribute for a multi-criteria decision methodology to be used with the experts, aiming to rank the technologies, projects and scenarios according to their social sustainability performance.

\section{Acknowledgment}

This work was financed by: the QREN - Operational Programme for Competitiveness Factors, the European Union - European Regional Development Fund and National Funds - Portuguese Foundation for Science and Technology, under Project FCOMP-010124-FEDER-011377 and Project Pest-OE/EME/UI0252/2011.

Annex l.

Survey of social impacts mentioned by the papers presented in Table 1.

\begin{tabular}{|c|c|c|}
\hline Number & Reference & Social impact \\
\hline 1 & (Kowalski, Stagl et al. 2009) [19] & Regional self-determinancy \\
\hline 2 & lbid. & Social cohesion \\
\hline 3 & Ibid. & Social justice \\
\hline 4 & Ibid. & Quality of landscape \\
\hline 5 & Ibid. & Noise \\
\hline 6 & Kahraman and Kaya [20] & $\begin{array}{l}\text { Compatibility with the national } \\
\text { energy policy objectives }\end{array}$ \\
\hline 7 & lbid. & Political acceptance \\
\hline 8 & lbid. & Social acceptance \\
\hline 9 & lbid. & Labour impact \\
\hline 10 & Karakosta et al. [21] & $\begin{array}{l}\text { Contribution to the net number } \\
\text { of employed persons as a result } \\
\text { of project implementation }\end{array}$ \\
\hline 11 & Ibid. & $\begin{array}{l}\text { Improvement in the quality of } \\
\text { life of weak populations }\end{array}$ \\
\hline 12 & Roth et al. [22] & Physical security \\
\hline 13 & Ibid. & $\begin{array}{l}\text { Political stability and } \\
\text { legitimacy }\end{array}$ \\
\hline 14 & Ibid. & Social development \\
\hline 15 & Ibid. & $\begin{array}{l}\text { Impacts on quality of } \\
\text { landscape \& residential areas }\end{array}$ \\
\hline 16 & lbid. & Impacts on human health \\
\hline 17 & lbid. & social components of risks \\
\hline 18 & Gamboa and Munda [23] & Municipalities income \\
\hline 19 & lbid. & Number of jobs \\
\hline 20 & lbid. & Visual impacts \\
\hline 21 & lbid. & Forest lost \\
\hline 22 & lbid. & Noise annoyance \\
\hline 23 & Ibid. & Avoided $\mathrm{CO}_{2}$ emissions \\
\hline 24 & Doukas et al. [24] & $\begin{array}{l}\text { Contribution to employment } \\
\text { opportunities' creation }\end{array}$ \\
\hline 25 & lbid. & $\begin{array}{l}\text { Contribution to regional } \\
\text { development }\end{array}$ \\
\hline 26 & GallegoCarrera and Mack [25] & System availability on demand \\
\hline 27 & lbid. & Diversity of energy suppliers \\
\hline 28 & Ibid. & Reserves and resources \\
\hline 29 & Ibid. & Waste management \\
\hline 30 & Ibid. & $\begin{array}{l}\text { Flexibility to respond to } \\
\text { market signals }\end{array}$ \\
\hline 31 & lbid. & $\begin{array}{l}\text { Flexibility to incorporate } \\
\text { technical developments }\end{array}$ \\
\hline 32 & lbid. & $\begin{array}{l}\text { Potential of conflicts induced } \\
\text { by energy systems }\end{array}$ \\
\hline 33 & Ibid. & $\begin{array}{l}\text { Willingness to act } \\
\text { (mobilization potential) }\end{array}$ \\
\hline 34 & lbid. & $\begin{array}{l}\text { Reliance on participative } \\
\text { decision-making processes }\end{array}$ \\
\hline 35 & Ibid. & $\begin{array}{l}\text { Citizens acceptance of the } \\
\text { system }\end{array}$ \\
\hline 36 & lbid. & $\begin{array}{l}\text { Perceived risk characteristics } \\
\text { for accidents }\end{array}$ \\
\hline 37 & Ibid. & $\begin{array}{l}\text { Perceived risk characteristics } \\
\text { for normal operation }\end{array}$ \\
\hline 38 & lbid. & Trust in risk management \\
\hline 39 & Ibid. & $\begin{array}{l}\text { Health effects from normal } \\
\text { operation }\end{array}$ \\
\hline 40 & lbid. & Health effects from accidents \\
\hline 41 & Ibid. & $\begin{array}{l}\text { Terrorists threat - potential for } \\
\text { attack }\end{array}$ \\
\hline 42 & lbid. & Effects on a successful assault \\
\hline 43 & lbid. & Equitable life conditions \\
\hline 44 & Ibid. & $\begin{array}{l}\text { Perception of the fairness of } \\
\text { risks }\end{array}$ \\
\hline 45 & Ibid. & $\begin{array}{l}\text { Effects on the quality of } \\
\text { landscape area }\end{array}$ \\
\hline 46 & Ferreira et al. [5] & Noiseimpact \\
\hline 47 & Ibid. & Impact on birds and wildlife \\
\hline 48 & lbid. & Visual impact \\
\hline 49 & lbid. & Social acceptance \\
\hline 50 & Beccali et al. [26] & Labour impact \\
\hline 51 & Ibid. & Market maturity \\
\hline
\end{tabular}




\begin{tabular}{|c|c|c|}
\hline Number & Reference & Social impact \\
\hline & lbid. & $\begin{array}{l}\text { Compatibility with political, } \\
\text { legislative and administrative } \\
\text { situation }\end{array}$ \\
\hline 53 & Cavallaro and Ciraolo [27] & Social acceptance \\
\hline 54 & lbid. & Impact on ecossystems \\
\hline 55 & lbid. & Acousticnoise \\
\hline 56 & lbid. & Visual impact \\
\hline 57 & Ibid. & $\mathrm{CO}_{2}$ emissions avoided \\
\hline 58 & Evans et al. [28] & Toxins \\
\hline 59 & lbid. & Visual \\
\hline 60 & Ibid. & Birdstrike \\
\hline 61 & lbid. & Noise \\
\hline 62 & lbid. & Displacement \\
\hline 63 & lbid. & Agricultural \\
\hline 64 & lbid. & River damage \\
\hline 65 & lbid. & Seismic activity \\
\hline 66 & Ibid. & Odour \\
\hline 67 & Ibid. & Pollution \\
\hline 68 & Vera and Langlois [29] & Accessibility of electricity \\
\hline 69 & lbid. & Affordability of electricity \\
\hline 70 & Ibid. & Disparities \\
\hline 71 & lbid. & Health/safety \\
\hline 72 & Assefa and Frostell [30] & Knorwledge \\
\hline 73 & Ibid. & Perception \\
\hline 74 & Ibid. & Fear \\
\hline 75 & Begic and Afgan [31] & Job \\
\hline 76 & Ibid. & Diversity \\
\hline 77 & Streimikiene and Sarvutyte [32] & $\begin{array}{l}\text { Technology-specific job } \\
\text { opportunities }\end{array}$ \\
\hline 78 & Ibid. & Food safety risk \\
\hline 79 & lbid. & $\begin{array}{l}\text { Fatal accidents from past } \\
\text { experience }\end{array}$ \\
\hline 80 & lbid. & $\begin{array}{l}\text { Severe accidents perceived in } \\
\text { future }\end{array}$ \\
\hline 81 & Alberts [33] & Noise \\
\hline 82 & lbid. & Wild life \\
\hline 83 & Krajnc and Domac [34] & $\begin{array}{l}\text { Possible impact on regional } \\
\text { unemployment }\end{array}$ \\
\hline 84 & Ibid. & $\begin{array}{l}\text { Avoided costs of } \\
\text { unemployment }\end{array}$ \\
\hline 85 & lbid. & $\begin{array}{l}\text { Self-sufficiency in electricity } \\
\text { production }\end{array}$ \\
\hline 86 & del Río and Burguillo [35] & Impactonemployment \\
\hline 87 & Ibid. & Demographical impacts \\
\hline 88 & lbid. & Energy impacts \\
\hline 89 & lbid. & Educational impacts \\
\hline 90 & Ibid. & $\begin{array}{l}\text { Impacts on the productive } \\
\text { diversification of the area }\end{array}$ \\
\hline 91 & Ibid. & $\begin{array}{l}\text { Integration in the local } \\
\text { economy (use of local } \\
\text { resources) }\end{array}$ \\
\hline 92 & lbid. & $\begin{array}{l}\text { Social cohesion and human } \\
\text { development }\end{array}$ \\
\hline 93 & lbid. & $\begin{array}{l}\text { Income distribution and } \\
\text { impact on poverty }\end{array}$ \\
\hline 94 & lbid. & $\begin{array}{l}\text { other economic benefits } \\
\text { (unrelated to employment) }\end{array}$ \\
\hline 95 & lbid. & $\begin{array}{l}\text { Involvement of local actors and } \\
\text { perception of the benefits of } \\
\text { the project }\end{array}$ \\
\hline 96 & lbid. & Impact on tourism \\
\hline 97 & lbid. & Creation of a local industry \\
\hline 98 & lbid. & $\begin{array}{l}\text { impact on the municipal } \\
\text { budget }\end{array}$ \\
\hline 99 & Werner and Schäfer [36] & Water quality and quantity \\
\hline 100 & Ibid. & Human resources \\
\hline 101 & lbid. & Social acceptance \\
\hline
\end{tabular}

\section{References}

[1] Commission, E., European Energy and Transport Trends To Whom It May Concern: 2030 - Update 2007. 2008, European Comission.

[2] Georgopoulou E, Sarafidis Y, Diakoulaki D. Design and implementation of a group DSS for sustaining renewable energies exploitation. European Journal of Operational Research 1998;109(2):483-500.

[3] Pohekar SD, Ramachandran M. Application of multi-criteria decision making to sustainable energy planning - A review. Renewable and Sustainable Energy Reviews 2004;8(4):365-81.
[4] Hobbs BF. Optimization methods for electric utility resource planning. Euro-pean Journal of Operational Research 1995;83(1):1-20.

[5] Ferreira P, Araújo M, O'Kelly MEJ, The integration of social concerns into electricity power planning: a combined Delphi and AHP approach, in Handbook of Power Systems, In: Rebennack S, et al., editors. 2010. pp. 323-364, 18.

[6] Brundtland GH. Our common future. World Commission on Economic Development 1988.

[7] Black A. The quest for sustainable, healthy communities, in effective sustainability education: what works? Why? Where next? Linking Research and Practice 2004 [Sydney, Australia].

[8] Biart M. Social sustainability as part of the social agenda of the Euro-pean community. Arbeiterkammer Wien, InformationenzurUmweltpolitik 2002;149:5-10 [Wien].

[9] Polese M, Stren R. The social sustainability of cities: diversity and the management of change. Toronto: University of Toronto Press; 2000.

[10] Sachs I. In: Becker E, Jahn T, editors. Social sustainability and whole development: exploring the dimensions of sustainable development. Sustainability and the social sciences. London: Zed Books; 1999.

[11] Griessler E, Littig B. Social sustainability: a catchword between political pragmatism and social theory. International Journal for Sustainable Development 2005;8(1/2):0960-1406

[12] Colantonio A, Social sustainability: linking research to policy and practice, in Sustainable development: a challenge for European research. 2009: Brussels.

[13] Vallance S, Perkins HC, Dixon J. What is social sustainability? A clarification of concepts. Geoforum 2011;42(3):342-8.

[14] Murray J, Dey C, Lenzen M. Systems for social sustainability: global connectedness and the Tuvalu test. Cybernetics and Human Knowing 2007;14(1):87-105.

[15] McKenzie S. Social sustainability: towards some definitions. Magil, Hawke Research Institute, University of South Australia; 2004.

[16] Harris J, Wise T, Gallagher K, Goodwin N. A survey of sustainable development: social and economic dimensions. Island Express 2001

[17] Benaim A, Collins A, Raftis L. Social dimension of sustainable development: guidance and application. Karlskrona: Blekinge Institute of Technology, Master; 2008. p. 127.

[18] Missimera M, Robèrta K, Bromana G, Sverdrup H. Exploring the possibility of a systematic and generic approach to social sustainability. Journal of Cleaner Production 2010;18(10-11):1107-12.

[19] Kowalski K, Stagl S, Madlener R, Omann I. Sustainable energy futures: method ological challenges in combining scenarios and participatory multi-criteria analysis. European Journal of Operational Research 2009;197(3):1063-74.

[20] Kahraman C, Kaya I. A fuzzy multicriteria methodology for selection among energy alternatives. Expert Systems with Applications 2010;37(9): 6270-81.

[21] Karakosta C, Doukas H, John P. EU-MENA energy technology transfer under the CDM: Israel as a frontrunner? Energy Policy 2010;38(5):2455-62.

[22] Roth S, Hirschberg S, Bauer C, Burgherr P, Dones R, Heck T, Schenler W. Sustainability of electricity supply technology portfolio. Annals of Nuclear Energy 2009;36(3):409-16.

[23] Gamboa G, Munda G. The problem of windfarm location: a social multi-criteria evaluation framework. Energy Policy 2007;35(3):1564-83.

[24] Doukas HC, Andreas BM, Psarras JE. Multi-criteria decision aid for the formulation of sustainable technological energy priorities using linguistic variables. European Journal of Operational Research 2007;182(2):844-55

[25] GallegoCarrera D, Mack A. Sustainability assessment of energy technologies via social indicators: results of a survey among European energy experts. Energy Policy 2010;38(2):1030-9.

[26] Beccali M, Cellura M, Mistretta M. Decision-making in energy planning. Application of the Electre method at regional level for the diffusion of renewable energy technology. Renewable Energy 2003;28(13):2063-87.

[27] Cavallaro F, Ciraolo L. A multicriteria approach to evaluate wind energy plants on an Italian island. Energy Policy 2005;33(2):235-44.

[28] Evans A, Strezov V, Evans TJ. Assessment of sustainability indicators for renewable energy technologies. Renewable and Sustainable Energy Reviews 2009;13(5):1082-8.

[29] Vera I, Langlois L. Energy indicators for sustainable development. Energy 2007;32(6):875-82.

[30] Assefa G, Frostell B. Social sustainability and social acceptance in technol-ogy assessment: a case study of energy technologies. Technology in Society 2007;29(1):63-78.

[31] Begic F, Afgan $\mathrm{NH}$. Sustainability assessment tool for the decision making in selection of energy system - Bosnian case. Energy 2007;32(10):1979-85.

[32] Streimikiene D, Sarvutyte M. Sustainability assessment of energy technologies. Ekonomika Ir Vadyba 2010;15.

[33] Alberts DJ. Stakeholders or subject matter experts, who should be consulted? Energy Policy 2007;35(4):2336-46.

[34] Krajnc N, Domac J. How to model different socio-economic and environmental aspects of biomass utilisation: case study in selected regions in Slovenia and Croatia. Energy Policy 2007:35(12):6010-20.

[35] del Río P, Burguillo M. An empirical analysis of the impact of renewable energy deployment on local sustainability. Renewable and Sustainable Energy Reviews 2008;13(6-7):1314-25.

[36] Werner M, Schäfer Al. Social aspects of a solar-powered desalination unit for remote Australian communities. Desalination 2007;203(1-3):375-93.

[37] Kilgour DM, Chen Y, Hipel KW. Multiple criteria approaches to group decision and negotiation. In: Ehrgott M, Figueira JR, Greco S, editors. Trends in multiple criteria decision analysis. US: Springer; 2010. p. 317-38. 
[38] Diakoulaki D, Antunes H, Martins A. MCDA and energy planning. In: Multiple criteria decision analysis: state of the art surveys. New York: Springer; 2005. pp. 859-890.

[39] Løken E. Use of multicriteria decision analysis methods for energy planning problems. Renewable and Sustainable Energy Reviews 2007;11(7):1584-95.

[40] Ferreira P. Electricity power planning in Portugal: the role of wind energy Guimarães: Departamento de Produc, ão e Sistemas, Universidade do Minho 2008.

[41] Upham P, Shackley S. The case of a proposed $21.5 \mathrm{MWe}$ biomass gasifier in Winkleigh, Devon: implications for governance of renewable energy planning. Energy Policy 2006;34(15):2161-72.

[42] Kaldellis JK. Social attitude towards wind energy applications in Greece. Energy Policy 2005;33(5):595-602.

[43] Gross C. Community perspectives of wind energy in Australia: the application of a justice and community fairness framework to increase social acceptance. Energy Policy 2007;35(5):2727-36.

[44] Swofford J, Slattery M. Public attitudes of wind energy in Texas: local communities in close proximity to wind farms and their effect on decision-making. Energy Policy 2010;38(5):2508-19.

[45] Eurobarometer, energy technologies. Knowledge, perception, measures. Luxembourg: European Communities; 2006

[46] Upreti BR, van der Horst D. National renewable energy policy and local opposition in the UK: the failed development of a biomass electricity plant. Biomass and Bioenergy 2004;26(1):61-9.

[47] Sjoberg L, Drottz-Sjoberg B-M. Public risk perception of nuclear waste. International Journal of Risk Assessment and Management 2009;11(3-4): 248 80.

[48] Wüstenhagen R, Wolsink M, Bürer MJ. Social acceptance of renewable energy innovation: an introduction to the concept. Energy Policy 2007;35(5): 2683-91.

[49] Wolsink M. Wind power and the NIMBY-myth: institutional capacity and the limited significance of public support. Renewable Energy 2000;21(1):49-64.

[50] Jobert A, Laborgne P, Mimler S. Local acceptance of wind energy: factors of success identified in French and German case studies. Energy Policy 2007;35(5):2751-60.

[51] Maruyama $Y$, Nishikido $M$, lida T. The rise of community wind power in Japan: enhanced acceptance through social innovation. Energy Policy 2007;35(5):27619.

[52] Loo vd. Mediating windpower in the Netherlands: the task force windpower implementation. 2001, Utrecht.

[53] Newman I, Benz C. Qualitative-quantitative research methodology: exploring the interactive continuum. Southern Illinois University Press; 1998.
[54] Ellis G, Barry J, Robinson C. Renewable energy and discourses of objection. Belfast: Queen's University; 2006.

[55] Devine-Wright P. Beyond NIMBYism: towards an integrated framework for understanding public perceptions of wind energy. Wind Energy 2005;8(2):125-39.

[56] Devine-Wright P. Reconsidering public attitudes and public acceptance of renewable energy technologies: a critical review. Manchester: School of Environment and Development, University of Manchester; 2007.

[57] Ansolabehere S, Konisky DM. Public attitudes toward construction of new power plants. Public Opinion Quarterly 2009:1-12.

[58] Wolsink M. Near-shore wind power - protected seascapes, environmental-ists attitudes, and the technocratic planning perspective. Land Use Policy 2010;27(2):195-203.

[59] Warren CR, McFadyen M. Does community ownership affect public attitudes to wind energy? A case study from South-West Scotland. Land Use Policy 2010;27(2):204-13.

[60] Itaoka H, Okuda Y, Saito A, Akai M. Influential information and factors for social acceptance of CCS: the 2nd round survey of public opinion in Japan. Energy Procedia 2009;1(1):4803-10.

[61] Achterberg P, Houtman D, van Bohemen S, Manevska K. Unknowing but supportive? Predispositions, knowledge, and support for hydrogen tech-nology in the Netherlands. International Journal of Hydrogen Energy 2010;35(12):6075-83.

[62] Brown S. A primer on Q methodology. Operant Subjectivity 1993;16(3/4): 91-138.

[63] Wolsink M, Breukers S. Contrasting the core beliefs regarding the effective implementation of wind power. An international study of stakeholder perspectives. Journal of Environmental Planning and Management 2010;53(5): 53558.

[64] Huijts NMA, Midden CJH, Meijnders AL. Social acceptance of carbon dioxide storage. Energy Policy 2007;35(5):2780-9.

[65] Rogers J, Simmons E, Converya I, Weatherall A. Public perceptions of opportunities for community-based renewable energy projects. Energy Policy 2008;36(11):4217-26.

[66] Bradbury J, Ray I, Peterson T, Wade S, Wong-Parodi G, Feldpausch A. The role of social factors in shaping public perceptions of CCS: results of multi-state focus group interviews in the U.S. Energy Procedia 2009;1(1):4665-72.

[67] Gough C, Shackley S. An Integrated assessment of carbon dioxide capture and storage in the UK. Manchester: Tyndall; 2005.

[68] Flynn R, Bellaby P, Ricci M. The limits of 'upstream' public engagement: citizens' panels and deliberation over hydrogen energy technologies. In: Society for Risk Analysis (Europe) Conference. 2009 